\title{
Fundamental rights under Covid-19: an European perspective on videoconferencing in court
}

\author{
Pierpaolo Gori $^{1}$ • Aniel Pahladsingh ${ }^{2}$
}

Accepted: 10 November 2020 / Published online: 2 December 2020

(C) @ ERA 2020

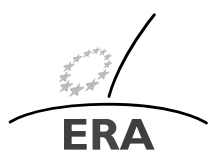

EUROPÄISCHE RECHTSAKADEMIE

ACADEMY OF EUROPEAN LAW ACADEMIE DE DROIT EUROPEEN ACCADEMIA DI DIRITTO EUROPEO TRIER - TREVES - TREVIRI

\begin{abstract}
The Covid-19 outbreak has challenged long-established legal procedures, the material functioning of the Court, the rule of law itself. In this article, videoconferencing in court proceedings is seen not only as an exceptional measure, but as possibly an effective part of the ordinary activity of courts. Fundamental rights at stake are taken into account, among them the European Convention on Human Rights and EU Charter rights of the defence, to effective remedies, to a fair trial, to be heard, to a public hearing and to privacy.

Human physical presence is invaluable. However, the current Covid 19 situation commands to treasure the earlier experience of the Spring 2020, and the absence of any ideological approach is desirable, whether this be in favour or against videoconferencing in Court.
\end{abstract}

Keywords Covid $19 \cdot$ Right to a fair trial · Public hearing ·

Court videoconferencing $\cdot$ Fundamental rights

\section{Introduction}

The Covid-19 outbreak has affected the world in dramatic fashion and led to emergency measures in most member states of the Council of Europe, aimed to contrast a deadly pandemic with few precedents in modern times. Restrictions on human rights

Disclaimer: All views expressed by the authors of this article are strictly personal and do not reflect the opinion of any Court.

P. Gori

Judge, Corte di Cassazione, Rome, Italy

2 EU lawyer at the Council of State and deputy judge, District Court of Rotterdam, Rotterdam, The Netherlands 
(as an effect of emergency measures) have been put in place and justified as exceptional measures to protect public health. ${ }^{1}$ Subsequently, in most countries, ordinary hearings, held physically in a courtroom, were no longer possible. This was notably the case from 9 March $2020^{2}$ in Italy, the first western country to be hit severely by the spread of the virus.

As a result, all pending ordinary proceedings were suspended until 11 May 2020 (in the case of civil and criminal proceedings) and until 15 May 2020 (in the case of administrative proceedings), ${ }^{3}$ with significant exceptions for urgent matters, which were expected to be regularly addressed by the courts and decided without delay. Such a goal was considered by the lawmaker to be compatible with respect for the right to life of defendants, lawyers, judges and for public health only by means of physical distance through the systematic use of videoconferencing in court hearings. ${ }^{4}$

Before the Covid-19 pandemic, videoconferencing in court was already used in Italy as a technical solution, in specific situations and the European Court of $\mathrm{Hu}-$ man Rights found no violation of Article 6 of the European Convention on Human Rights. ${ }^{5}$ For instance, minors heard as witnesses in trials for sexual abuse or a per-

\footnotetext{
${ }^{1}$ The UN Human Rights office of the High Commissioner on 27 April 2020 adopted guidelines for emergency measures and Covid-19. Restrictions on such fundamental liberties have to meet four requirements (legality, necessity, proportionality, non discrimination): "The restriction must be 'provided by law' (...) of general application (...) not be arbitrary or unreasonable, and it must be clear and accessible to the public. (...) necessary for the protection of one of the permissible grounds stated in the ICCPR, which include public health, and must respond to a pressing social need. (...) proportionate to the interest at stake (...) and it must be the least intrusive option among those that might achieve the desired result. (...). No restriction shall discriminate contrary to the provisions of international human rights law." <https://www.ohchr.org/Documents/Events/EmergencyMeasures_COVID19.pdf>, visited 8 November 2020 .

${ }^{2}$ Art. 1 of Decree-law no. 11, published in the Official Gazette on 8 March 2020. For a commentary, P. Gori, "Covid-19: la Cassazione apre alle udienze da remoto' <www.questionegiustizia.it>, visited 8 November 2020. A key provision adopted a few days later is Art. 83 of Law-decree 17 March 2020, No. 18 (as further modified), carrying out urgent measures in the field of civil, criminal, tax and military justice in order to deal with the epidemiological emergency from Covid-19, resulting in: 1) postponement of all hearings scheduled from 9 March to 11 May (civil and criminal matters), 2) limitation of access to courts, whereas it is ensured that urgent civil and criminal activities are carried out, 3) suspension of the expiry of the terms for the carrying out of any procedural act, including the terms for starting judicial proceedings and the terms for the notification of appeals before the upper courts; 4) the expiry of the term for the carrying out of a procedural act that begins during the suspension period is deferred to the end of the above-outlined period. This complex procedural regulation has been converted in Law no. 27, published in the Official Gazette on 29 April 2020.

${ }^{3}$ See Decree-law no. 23 on urgent measures regarding, inter alia, the extension of administrative and procedural terms, published in the Official Gazette on 8 April 2020.

${ }^{4}$ This practice is consistent with European Law Institute (ELI) guidelines for the Covid-19 Crisis:
}

\footnotetext{
"The judiciary should do all that is reasonably practicable to continue to conduct proceedings and trials, particularly through the use of secure video and other remote links where available to the courts (...) provided that the right to a fair trial, including the right to defence, is not infringed. The restrictions on the operation of the judiciary must be immediately removed when the Covid-19 emergency permits."
}

See Principle 5 ‘Justice System’ 2020 <https://www.europeanlawinstitute.eu/>, visited 8 November 2020. ${ }^{5}$ ECtHR 5 October 2006, No. 45106/04, Marcello Viola v Italy (No. 1), CE:ECHR:2006: 1005JUD004510604, paras 21-2: provided that the relevant Italian regulation demands that certain 'results' have to be attained and, in particular, the 'effective' participation of the accused in the proceedings 
son who, in any capacity, was detained in a prison regarding mafia-related and other serious offences ${ }^{6}$ could already take advantage of such technology.

However, the exceptional measures adopted in March and April $2020^{7}$ to govern the health crisis introduced for the first time the idea of a possible full legal procedure being carried out through videoconferencing instead of by the parties being physically present in court. This is the case for urgent criminal matters like trials of arrested persons, where the exercise of the police power of arrest needs by law to be validated within 48 hours by a court. ${ }^{8}$

Such a new approach raises a number of questions, regarding its compatibility with key fundamental rights - namely respect for privacy, due to the specific technology adopted for court videoconferencing, ${ }^{9}-$ and more generally with the right to be heard in court, the right of defence, the right to effective judicial remedies and the right to a fair trial. The issue is expected to be salient in the future, at least in the event of the

with a view to ensuring the proper exercise of his right to a defence, and contact between the accused and his defence counsel, present where the defendant is situated with the ability to communicate with each other, "in the opinion of the [Italian] Constitutional Court, the fact that the new provisions departed from 'tradition' did not upset the balance and dynamics of a trial that, on the contrary, remained substantively unchanged.’. Finally, the Court found no violation under Article 6 (1) ECHR.

${ }^{6}$ Law no. 11 of 7 January 1998 introduced, among the implementing provisions of the Italian Code of Criminal Procedure, Art. 146-bis which, as later amended, reads as follows:

"1. In proceedings concerning one of the offences provided for (...) a person who, in any capacity, is detained in a prison shall participate in the hearings in videoconference (...): (a) where there are serious requirements of public safety or order; (b) where the proceedings are particularly complex and participation at a distance is deemed necessary in order to avoid delays (...)

5. The place from which the accused is connected by audiovisual link to the hearing room shall be regarded as an extension of the hearing room. (...)".

${ }^{7}$ In some cases procedural measures were adopted by authorities other than the Government, such as the Constitutional Court - which is not part of the ordinary judiciary and it is not considered a judicial body in the classic sense. See Decree of the Court's president 24 March 2020 'Ulteriori misure per lo svolgimento dei giudizi davanti alla Corte costituzionale durante l'emergenza epidemiologica da COVID-19' (new procedural regulations) and the commentary from P. Costanzo, 'Con l'emergenza decolla la Corte 2.0' $<$ www.giurcost.org $>$ visited 8 November 2020.

${ }^{8}$ See the Guidelines for urgent criminal matters, adopted on 20 April 2020 by the Court of Rome, for an example of best practices enforced during the Covid-19 pandemic to prevent the stop of the jurisdiction $<w w w . a l t a l e x . c o m>$, visited 8 November 2020. The Consiglio superiore della magistratura (the central body for self-government within the judiciary) already on 5 March 2020 adopted guidelines to coordinate emergency organisational planning from all judicial offices <www.csm.it>, visited 8 November 2020 .

${ }^{9}$ Privacy issues were immediately raised by a proactive association of Italian criminal lawyers (the Unione camere penali), since no videoconferencing tools specifically designed for court proceedings had been adopted by the legislator. In need of an urgent solution, the Government choose general business products immediately available on the market ('Teams' and 'Skype for Business'). These products were already experimented within the Ministry of Justice.

On 19 April 2020 the Italian Privacy Authority asked the Ministry a full disclosure of information about data treatment and storage from Microsoft tools used in criminal proceedings in the framework of the emergency Covid-19 measures <https://www.garanteprivacy.it/home/docweb/-/docweb-display/docweb/ 9316889> visited 8 November 2020. On 21 May 2020, the Authority found that the tools chosen in administrative proceedings would be compatible with the relevant privacy regulation on condition that a few improvements were made <https://www.gpdp.it/web/guest/home/docweb/-/docweb-display/ docweb/9347225> visited 8 November 2020 . 
return of exceptional conditions, not to mention the possibility that videoconferencing in court hearings may become an ordinary procedural tool. ${ }^{10}$

Emergency legislation governing the Covid-19 crisis in the Netherlands is very interesting as well. A bill proposed by the Dutch government was adopted by the Senate, and published on 24 April 2020. ${ }^{11}$ The emergency legislation was set to cease to apply on 1 September 2020. As it couldn't be excluded that temporary legislation would still be needed after this date, the law included a clause providing for extensions (of two months each time) which is now extended until 30 November $2020 .^{12}$ Some provisions in the Bill have taken effect retroactively to 16 March 2020.

The judiciary is in general now allowed to make greater use of electronic means of communication. Video links are already in use for oral proceedings and may be applied more frequently in the future, for example, so that lawyers or parties to proceedings no longer need to appear in person, given that video call technology suffices.

In several European States, emergency measures adopted have been challenged before national administrative high courts ${ }^{13}$ and several judgments have already been delivered. ${ }^{14}$ Such a judicial check on central and local governmental action appeared to be a key remedy in democratic societies since many parliaments could not sit and operate properly for a substantial period due to the pandemic. ${ }^{15}$

\footnotetext{
${ }^{10}$ For instance, since the beginning of the twenty-first century, Portuguese courts have systematically used videoconferencing either in internal Court proceedings, e.g., for taking witnesses from overseas territories, or to effect the taking of evidence in cross-border proceedings, under the following structures: 1) Regulation (CE) n.1206/2001 for EU Countries, 2) the Iberoamerican Judicial Network, an informal structure since 2005 through national contact points for South and Central American Countries, 3) the Convention on the taking of evidence abroad in civil and commercial matters signed on 18 March 1970 (applicable to countries that ratified it), 4) Reciprocity for the rest of the world (source: Carlos Marinho, judge at the Court of Appeal of Lisbon).

${ }^{11}$ See Staatsblad, 2020, 124.

${ }^{12}$ See Staatsblad 2020, 364: all measures are extended until 30 November 2020.

${ }^{13}$ Conseil d'état, 28 March $2020-\mathrm{n}^{\circ} 439726$ on a request that the Government provide masks, screening tests and medicine (hydroxychloroquine) to the general public; $\mathrm{n}^{\circ} 439765$ on the same medicine; $\mathrm{n}^{\circ}$ 439693 on masks, hydroalcoholic solution and other personal protection equipment for medical staff; $\mathrm{n}^{\circ}$ 439720 on the temporary shut-down of administrative detention centers for aliens awaiting removal. As references of reviews on Covid-19 measures in front of Constitutional courts, see one individual application Bundesverfassungsgericht 12 May 2020, BvR 1027/20, DE:BVerfG:2020:rk20200512.1bvr102720; as an example of the mechanism of Article 61 of the French Constitution operating a preliminary control of constitutionality on the matter, see Conseil constitutionnel, décision n.2020-800 DC du 11 Mai 2020, FR:CC:2020:2020.800.DC. (Summaries of these judgments can be found in Jurifast 'ACA Europe' $<$ http://www.aca-europe.eu/index.php/en/jurifast-en.> visited 8 November 2020.)

${ }^{14}$ District Court, The Hague 3 April 2020, NL:RBDHA:2020:3013 on an application (temporary injunction) where the plaintiffs requested a 'full lockdown' to be imposed. This application was dismissed on 3 April 2020. (A summary of this judgment can be found in Jurifast 'ACA Europe'.)

${ }^{15}$ Most Italian Covid-19 statutory law was adopted by the Government and by regional presidents with little initial control from the Parliament, which was not able to work effectively for weeks, due to the sanitary emergency. Effective parliamentary control over statutory law came only with the conversion of the urgent law decrees into law, almost sixty days after the first provisional regulation was adopted by the Government.
} 


\section{Effective remedies and the right to a fair trial under the European Convention on Human Rights and Fundamental Freedoms}

The existence of effective remedies is, for Member States of both the EU ${ }^{16}$ and party states to the European Convention on Human Rights (not to mention the national protection afforded by Member States Constitutions), a fundamental right. It is a right enshrined in Article 47 of the Charter of Fundamental Rights of the European Union; as well as being an essential pre-condition for an effective human rights policy, ${ }^{17}$ serving as it does other substantive and procedural human rights, namely the right to a fair trial under Article 6 of the European Convention on Human Rights; and beyond this an autonomous human right protected by Article 13 of the Convention. ${ }^{18}$

The case-law of the European Court of Human Rights has shown significant evolution in interpreting the scope of Articles 6 and 13. Reference to the case-law is essential in order to understand the interactions between the two provisions, according to the 'living instrument doctrine'. ${ }^{19}$ In the earlier elaborations by Convention bodies, the Commission ${ }^{20}$ would very often find a violation under Article 6, or another provision of the Convention, separate from Article 13. Subsequently, the Court would rule that it was not necessary to examine also the applicant's case under the latter provision, the supposed "less strict" requirements of which were held to be "absorbed".

This initial approach was consistent until the Airey judgment, ${ }^{21}$ where three different dissenting opinions rooted for the first time the 'effective remedy issue' not only in the requirements of Article 6, but in Article 13 as well. In order to fully weigh the line of reasoning in the dissenting opinions in Airey, (substantially shared by important scholars) $)^{22}$ and to understand why this line later prevailed, it is important to recall how the right to a fair trial has been interpreted by the Court's consistent case-law.

According to Article 6(1) "in the determination of his civil rights and obligations" (the civil limb of this provision), "or of any criminal charge against him" (the criminal limb), "everyone is entitled to a fair [hearing]". A definition of the notion of fairness can be found in Užukauskas, where the Court reiterated that the principle of equality

\footnotetext{
${ }^{16}$ In the negotiations leading up to the signing to the Lisbon treaty, the UK and Poland secured a Protocol on the application of the Charter in their respective Countries, adopting an opt-out clause. See P Jeney, 'The Opt Outs' (2011) <e-justice.europa.eu> visited 8 November 2020.

${ }^{17}$ See M Kuijer, 'Effective Remedies as Fundamental Right' (2014) <www.ejtn.eu>, visited 8 November 2020.

${ }^{18}$ Similar core rights to access to justice are also provided for in other international instruments, such as Articles 8 and 10 of the UN Universal Declaration of Human Rights, and Articles 2(3) and 14 of the UN International Covenant on Civil and Political Rights.

${ }^{19}$ ECtHR 25 April 1978, No. 5856/72, Tyrer v UK, CE:ECHR:1978:0425JUD000585672.

${ }^{20} \mathrm{R}$ Glas, 'Changes in the Procedural Practice of the European Court of Human Rights: Consequences for the Convention System and Lessons to be Drawn', (2014) 14 Human Rights Law Review 671.

${ }^{21}$ ECtHR 9 October 1979, No. 6289/73, Airey v Ireland, CE:ECHR:1979:1009JUD000628973.

${ }^{22} \mathrm{E}$ Bates, The Evolution of the European Convention on Human Rights (Oxford University Press 2010) 345; P Van Dijk, GJH van Hoof, Theory and practice of the European Convention on Human Rights, (3rd ed., Kluwer, 1998) 717. For the interpretation of the relevant Strasbourg Court case-law, BM Zupančič, 'On the interpretation of Legal Precedents and of the Judgments of the European Court on Human Rights' (2007) Annual of German and European Law, Volumes 1 and 2.
} 
of arms is part of the broader concept of a fair hearing and requires each party to be given a reasonable opportunity to present his or her case under conditions that do not place the litigant at a substantial disadvantage vis-à-vis the opponent. ${ }^{23}$

Hearings need to be held in public, because this public character protects litigants against the administration of justice without public scrutiny. Such fundamental principle is also one of the means whereby people's confidence in the courts can be maintained. Publicity - by rendering the administration of justice transparent - contributes to the achievement of the fair trial. ${ }^{24}$

Again, although Article 6(1) does not provide for a right of access to national courts or tribunals in express terms, the words of the provision, taken in their specific context to Article 13 and Article 5(4) Convention, ${ }^{25}$ nonetheless provide reason to think that such a right is included among the guarantees set forth. Therefore an impediment to access to the national courts - and thus a deprivation in fact of the right to lodge a successful case - will affect the right to a fair trial. ${ }^{26}$

Legal proceedings are considered to constitute a fair trial according to Article 6 only if the outcome comes "within a reasonable time", with guarantees of independence and impartiality, ${ }^{27}$ from a "tribunal established by law". 28

In contrast, Article 13 - itself headed 'Right to an effective remedy' - does not necessarily refer to a court, since it refers to 'a national authority', and has to be read

${ }^{23}$ ECtHR 6 July 2010, No. 16965/04, Užukauskas v Lithuania, CE:ECHR:2010:0706JUD001696504, paras $45-46$.

${ }^{24}$ ECtHR 2 October 2012, No. 18498/04, Khrabrova v Russia, CE:ECHR:2012:1002JUD001849804, para 48.

${ }^{25}$ Detention orders have been found by the ECtHR to be ex facie invalid in cases where the interested party did not have proper notice of the hearing, 8 November 2005, No. 6847/02, Khudoyorov v Russia, CE:ECHR:2005:1108JUD000684702, para 129. Under the procedural aspect of Art. 5 ECHR the 'officer' is not considered identical with the 'judge' but must nevertheless have some of the latter's attributes. (4 December 1976, No. 7710/76, Schiesser v Switzerland, CE:ECHR:1979:1204JUD000771076, para 31), and therefore is met by the obligation of hearing the individual in person prior to taking the appropriate decision on personal freedom.

${ }^{26}$ For the 'right to hearing' and 'to access to court', landmark case is ECtHR 21 February 1975, No. 4451/70, Golder v UK, CE:ECHR:1975:0221JUD000445170, paras 28, 31 and 32

\begin{abstract}
"The clearest indications are to be found in the French text, first sentence. In the field of "contestations civiles' (civil claims) everyone has a right to proceedings instituted by or against him being conducted in a certain way - 'équitablement' (fairly), 'publiquement' (publicly), 'dans un délai raisonnable' (within a reasonable time), etc. - but also and primarily 'à ce que sa cause soit entendue' (that his case be heard) not by any authority whatever but 'par un tribunal' (by a court or tribunal) within the meaning of Article 6 para. 1 (art. 6-1) (...).".
\end{abstract}

${ }^{27}$ For the notion of 'independence' and 'impartiality', see ECtHR 3 July 2012, No. 10987/10, Ibrahim Gürkan v Turkey, CE:ECHR:2012:0703JUD001098710, para 13, stressing, inter alia, the importance of "the manner of appointment of its members and their term of office, the existence of guarantees against outside pressures".

${ }^{28}$ ECtHR 4 April 2013, Nos. 21565/07 et al., Julius Kloiber Schlachthof GmbH and Others v Austria, CE:ECHR:2013:0404JUD002156507, para 28: "A 'tribunal' is characterised in the substantive sense of the term by its judicial function, that is to say determining matters within its competence applying the law and after proceedings conducted in a prescribed manner.". In Steininger, the ECtHR found that neither the Austrian Administrative Court nor the Constitutional Court qualified as a tribunal, 17 April 2012, No. 21539/07, Steininger v Austria, CE:ECHR:2012:0417JUD002153907, paras 13-28. 
together with Article 35 of the Convention: an applicant should however have normal recourse to the remedies available in the Member State, which should be sufficient to afford redress in respect of the breaches alleged, not only in theory but also in practice, failing which they will lack the requisite accessibility and effectiveness. ${ }^{29}$

Both Articles 6 and 13 enshrine no absolute rights, and therefore can be balanced with other rights protected by the European Convention on Human Rights. For instance, during the Covid-19 outbreak, such rights needed to be balanced by legislators and by Courts with the protection of public health and with the absolute right to life itself. ${ }^{30}$

Taking into account the relative nature of the protection afforded by Article 6, both substantially and procedurally, and also by Article 13, there is no absorption or overlapping of the latter provision into the former in principle. ${ }^{31}$ Three key points deserve to be underlined at this regard: first, a complaint under Article 13 can be of a nature other than that of one made by an applicant under Article 6. Secondly, a 'lex specialis approach' between the two provisions is justified if the Court, as well as the national judge dealing with the matter at the national level, assesses in its test under Article 6 whether there had been a lack of effective remedies. Finally, the effectiveness of a remedy does not depend on the certainty of a favourable outcome for the applicant. ${ }^{32}$

Therefore, the applicability of Article 6(1) in a specific case often does not automatically rule out the applicability of Article $13,{ }^{33}$ with each covering distinct aspects of the exercise of the right of the defence. Recently, however, the Strasbourg Court viewed the two redress provisions as alternative in important matters, such as in relation to the length of the proceedings ${ }^{34}$ and in immigration cases. The European Court of Human Rights has found a violation of Article 6(1) only - although the applicants relied on Article 13 as well - by virtue of the absence of an effective judicial procedure determining whether evidence held by prosecution should be disclosed to the defence. ${ }^{35}$ In Matanović, for instance, the grievance under Article 13 was declared in-

\footnotetext{
${ }^{29}$ ECtHR 1 March 2006, No. 56581/00, Sejdovic v Italy, CE:ECHR:2006:0301JUD 005658100, para 46.

${ }^{30}$ Right to life and Prevention of torture (Articles 2 and 3 ECHR) are absolute rights, allowing no compression in principle.

${ }^{31}$ Sharp is the dissenting opinion of Judge Evrigenis, para 3, annexed to ECtHR, Airey v Ireland, supra $\mathrm{n}$. 19: "The Court should, in my opinion, have undertaken an examination of the claim based on the violation of Article 13 (...). The judicial proceedings contemplated by Article 6 para. 1 concern civil rights, in the present case the right to a judicial separation. On the other hand, the remedy mentioned in Article 13 refers to the fundamental rights protected by the Convention, in the present case the right of access to the courts, as it results from Article 6 para. 1. Accordingly, there was not any overlapping or absorption as regards the two provisions".

${ }^{32}$ ECtHR 25 March 1993, No. 13134/87, Costello-Roberts v the United Kingdom CE:ECHR:1993: 0325JUD001313487, para 40.

${ }^{33}$ S Jansen, Towards an Adjustment of the Trias Politica, 42, mentioning his own and T Barkhuysen's findings, F. Stroink and E van der Linden (eds), Judicial Lawmaking and Administrative Law, (IntersentiaOxford 2005).

${ }^{34}$ ECtHR 26 October 2000, No. 30210/96, Kudta v Poland, CE:ECHR:2000:1026JUD003021096, paras 146-9.

${ }^{35}$ ECtHR 4 April 2017, No. 2742/12, Matanović v. Croatia, CE:ECHR:2017:0404JUD000274212.
} 
admissible as manifestly ill-founded due to Article 35(3) of the European Convention on Human Rights.

An excessively formalistic interpretation of procedural rules preventing access to a supreme court could also be relevant ${ }^{36}$ according to the Chamber judgment in Zubac. ${ }^{37}$ More generally, there is a trend of relying solely on Article 6 in complaining of a lack of effective remedies in cases where the applicants have suffered violations because of procedural mistakes made by a State authority, namely courts, for which the applicants should have borne no responsibility, causing disproportionate hindrance in the right of access to a court or tribunal. ${ }^{38}$ This may be also the case where a ruling dismisses an appeal for being lodged out of time, even though the delay has mainly resulted from the conduct of another court in transferring the request to the competent one. ${ }^{39}$ Article 6(1) has in this situation been considered by the Court as constituting a lex specialis in relation to Article $13,{ }^{40}$ and the conduct has been ultimately found in breach of Article 6(1).

The survey conducted shows that the right to an effective remedy may well be defined as being of an autonomous but subsidiary character, ${ }^{41}$ and this is relevant for an evaluation of Covid-19 emergency regulations, because a breach of Article 13 would in principle not depend on finding a breach of the Article 6(1) right to a fair trial. What the obligations of a State are under Article 13 could be established only by taking into account the exact nature of each Convention claim.

\section{The right to an effective remedy under the European Convention on Human Rights and under the Charter of Fundamental Rights of the European Union}

In comparison with the European Convention on Human Rights, the Charter of Fundamental Rights of the European Union is a young instrument within the EU - indeed,

\footnotetext{
${ }^{36}$ ECtHR 11 October 2016, No. 40160/12, Zubac v Croatia, CE:ECHR:2016:1011JUD004016012.

${ }^{37}$ However, such ruling has been redressed by a Grand Chamber ruling declaring that in the specific circumstances no violation of Article 6(1) occurred having regard for both legal certainty and proper administration of justice, ECtHR 5 April 2018, No. 40160/12, Zubac v Croatia CE:ECHR:2018:0405JUD004016012, para 123.

${ }^{38}$ For a decision declaring an application inadmissible as being served on the respondent party out of time, even though it had been the court bailiff's responsibility to effect service, ECtHR 11 January 2001, No. 38460/97, Platakou v Greece CE:ECHR:2001:0111JUD003846097, para 49.

${ }^{39}$ ECtHR 19 July 2007, No. 71440/01, Freitag v Germany CE:ECHR:2007:0719JUD007144001, para 41.

${ }^{40}$ See for another example, ECtHR 30 April 2014, No. 15253/10, Šimecki v Croatia CE:ECHR:2014: 0430JUD001525310, para 53.

${ }^{41}$ Art. 1 ECHR provides: "The High Contracting Parties shall secure to everyone within their jurisdiction the rights and freedoms defined in Section I of [the] Convention": national authorities are primary entrusted with implementing and enforcing the rights and freedoms guaranteed by the Convention, and review by the ECtHR is thus subsidiary to national systems safeguarding human rights. This subsidiary character is enshrined in Articles 13 and 35(1) of the Convention: ECtHR 29 March 2006, No. 36813/97, Scordino v Italy (No. 1), CE:ECHR:2006:0329JUD003681397, para 140.
} 
a 'millennial'42 - although the fundamental right to effective remedies was already protected by the Court of Justice of the European Union before the Charter came about. ${ }^{43}$ Article 47 of the Charter encompasses the scope of both Article 6 and Article 13 of the Convention since it is headed the "right to an effective remedy" 44 and to a fair trial" 45 before a tribunal. ${ }^{46}$ Article 47(3) of the Charter specifies that "everyone shall have the possibility of being advised, defended and represented'.

In $D E B,{ }^{47}$ an energy-providing company lodged a case against the German State for delaying the implementation of two EU Directives, which it claimed led to financial losses. The company said it lacked the means to pay the court fees or the lawyer required by the applicable Code of procedure because of such losses. In Germany, litigants were required to arrange legal representation, but legal aid for legal persons was available under 'exceptional circumstances' only. The German court referred the issue to the Court of Luxembourg, which ruled that such a provision must be interpreted as meaning that it is not impossible for legal persons to rely on the principle of effective judicial protection under Article 47 "and that aid granted pursuant to that principle may cover, inter alia, dispensation from advance payment of the costs of proceedings and/or the assistance of a lawyer." 48

Is this line of reasoning now to be further extended to cover the costs of access to justice for both physical and legal persons through videoconferencing? Such technology in fact requires several preconditions to be put in place, namely the ability of both the administration of justice and the lawyers to use the tools and the capacity and stability of the wide band to sustain the stream of information. Those elements cannot be given for granted on the part of all persons involved in court proceedings (such as witnesses, disadvantaged defendants and detained persons) and require specific

${ }^{42}$ For the first time proclaimed in Nice on 17 December 2000, published on the official journal of the
European Communities 2000/C 364/01. The Charter is legally binding since 1 December 2009. See for the
most recent published version of the Charter OJ C 326, 26 October 2012, 391-407.

${ }^{43}$ ECJ 23 April 1986, Case C-294/83, Parti écologiste "Les Verts", EU:C:1986:166.

${ }^{44}$ Article 47(1) reads: "Everyone whose rights and freedoms guaranteed by the law of the Union are violated has the right to an effective remedy before a tribunal in compliance with the conditions laid down in this Article". For interesting findings about the right to hearing, see ECJ 18 October 2011, Case C-128/09, Antoine Boxus EU:C:2011:667, para 26., about the compatibility with the right of access to justice, guaranteed by Council Directive 85/337/EEC of 27 June 1985 as well, regarding a national act with legislative status whose adoption has the consequence that the referring court can no longer hear cases already brought before it.

${ }^{45}$ Article 47(2) states: "Everyone is entitled to a fair and public hearing within a reasonable time by an independent and impartial". About the notion of independence and impartiality, see ECJ 1 July 2008, Case C-341/06 and C-342/06, Chronopost SA and La Poste, EU:C:2008:375, para 46.

${ }^{46}$ For a definition of tribunal, with results similar to ECtHR findings, check ECJ 31 January 2013, Case C-394/11, Valeri Hariev Belov, EU:C:2012:585.

${ }^{47}$ ECJ 22 December 2010, Case C-279/09, $D E B ~ m b H$, EU:C:2010:811. Legal aid shall be made available to those who lack sufficient resources in so far as such aid is necessary to ensure effective access to justice.

48"Review of the case-law of the European Court of Human Rights shows that, on several occasions, that court has stated that the right of access to a court constitutes an element which is inherent in the right to a fair trial under Article 6(1) of the ECHR." ECJ, DEB mbH, supra n. 45, para 45. To reach such findings, the $D E B$ judgment referred to the 'horizontal clause' of Article 52(3): where Charter rights correspond to ECHR rights, the meaning and scope of those rights are the same, although more extensive protection can be provided. 
technical assistance and safe points of connection, fully compliant with the relevant Privacy regulation.

Article 13 of the European Convention on Human Rights sets out the right to an effective remedy before a national authority for arguable violations of any human right protected under the Convention. It requires the provision of at least a remedy before a national authority, ${ }^{49}$ effective in practice as well as in law. ${ }^{50}$ Article 13 as applied by the Strasbourg Court is the basis for interpreting Article 47 of the Charter, but the latter provides a more extensive protection in accordance with its partially different scope. Article 47 covers rights and freedoms guaranteed by EU law, essentially when Member States are implementing it. A possibility of redress through a full review of the facts before a proper tribunal, and not merely a national authority with decisional capacity, is required. These remedies - for an aggregate protection may be, as a whole, sufficient - have also to be qualified by substantive $\mathrm{e}^{51}$ and institutional conditions. ${ }^{52}$

Finally, in order to comply with the principle of equivalence, the conditions governing claims arising from EU law can not be less favourable than those relating to similar actions arising from national law. ${ }^{53}$

\section{The right to be heard as part of the right of the defence}

The Strasbourg Court declared in Colozza ${ }^{54}$ that the defendant's right to be physically present at his or her trial serves the effectiveness of other rights protected by the European Convention on Human Rights as well. Is exercising the right to examine witnesses or to be assisted by an interpreter or even to defend oneself possible without a physical presence in court - a requirement imposed by the exceptional measures to combat coronavirus?

In Poitrimol $^{55}$ the Court affirmed that a waiver of the right to take part in a trial must be established in an unequivocal manner and must be attended by minimum

${ }^{49}$ Substantive requirements for effectiveness are outlined by ECtHR 10 September 2010, No. 31333/06, McFarlane v Ireland, CE:ECHR:2010:0910JUD003133306; for institutional requirements, see ECtHR 4 July 2006, No. 59450/00, Ramirez Sanchez v France, CE:ECHR:2006:0704JUD005945000.

${ }^{50}$ ECtHR 4 May 2000, No. 28341/95, Rotaru v Romania, CE:ECHR:2000:0504JUD002834195, para 67.

${ }^{51}$ ECJ 3 October 2013, Case C-583/11 P, Inuit Tapiriit Kanatami, EU:C:2013:625.

${ }^{52}$ ECJ 28 July 2011, Case C-69/10, Brahim Samba Diouf, EU:C:2011:524.

${ }^{53}$ ECJ 7 December 2010, Case T-49/07, Sofiane Fahas, EU:T:2010:499, para 59:

"the principle of effective judicial protection is a general principle of Community law stemming from the constitutional traditions common to the Member States, which has been enshrined in Articles 6 and 13 of the ECHR and has also been reaffirmed by Article 47 of the Charter of fundamental rights of the European Union, proclaimed on 7 December 2000 at Nice".

${ }^{54}$ ECtHR 12 February 1985, No. 9024/80, Colozza v Italy, CE:ECHR:1985:0212JUD000902480, para 28 develops and interesting reasoning on the burden of proof: "In conclusion, the material before the Court does not disclose that Mr. Colozza waived exercise of his right to appear and to defend himself or that he was seeking to evade justice."

${ }^{55}$ ECtHR 23 November 1993, No. 14032/88, Poitrimol v France, CE:ECHR:1993:1123JUD00140328838, para 31: 
safeguards commensurate to its importance. The right to be present in court needs typically to be exercised in the first instance. According to established case-law, there is no unconditional right to appear personally before a panel of judges on appeal or in front of a court of cassation. The case-law is consistent in denying this, even if it is within the capacity of the upper court to examine both issues of law and of facts, in a full review, with exceptions mostly related to incorrect exercises of the right to be heard in first instance, before the review in appeal or cassation. ${ }^{56}$ The underlying line of reasoning is that the courts concerned do not have the task of establishing the facts of the case, but rather only that of interpreting the legal rules involved.

In Kamasinski, the Strasbourg Court set out the principle according to which the presence in person of the accused at a hearing of an appeal where only points of law are considered is not crucial. ${ }^{57}$ In any case, even where high courts have jurisdiction to review a case both as to facts and as to law, Article 6 does not always require necessarily a right to a public hearing and a fortiori a right to be present in person, irrespective of the nature of the issue to be decided. ${ }^{58}$ According to the Fejde case, other points must be taken into account, including the right to trial within a reasonable period and the related need for compliance with the 'reasonable time' requirement which is protected by Article 6, which must be considered in determining the need for a public hearing and the need for personal appearance before the appellate court on appeal and possibly at third instance.

Account must be taken of the entirety of the proceedings and of the role of the court of appeal therein ${ }^{59}$ and, inter alia, the special features of the proceedings involved and the manner in which the interests of the defence have been presented and protected at first instance, particularly in the light of the issues to be settled, ${ }^{60}$ and having regard for their importance for the defendant as well. What is really needed is

"The Court considers that the inadmissibility of the appeal on points of law, on grounds connected with the applicant's having absconded, also amounted to a disproportionate sanction, having regard to the signal importance of the rights of the defence and of the principle of the rule of law in a democratic society."

${ }^{56} \mathrm{ECtHR}$, Marcello Viola v Italy (No. 1), supra n. 5, para 55.

${ }^{57}$ ECtHR 19 December 1989, No. 9783/82, Kamasinski v Austria, CE:ECHR:1989:1219JUD000978382, para 106:

"However, the personal attendance of the defendant does not take on the same crucial significance for an appeal hearing (...) as it does for the trial hearing (...). Consequently, this is an area where the national authorities enjoy a margin of appreciation in assessing whether and to what extent differences in otherwise similar situations justify a different treatment in law".

${ }^{58}$ ECtHR 29 October 1991, No. 12631/87, Fejde v Sweden, CE:ECHR:1991:1029JUD001263187, para 31.

${ }^{59}$ ECtHR 26 May 1988, No. 10563/83, Ekbatani v Sweden, CE:ECHR:1988:0526JUD001056383, para 27.

${ }^{60}$ ECtHR 29 October 1991, No. 11826/85, Helmers v Sweden, CE:ECHR:1991:1029JUD001182685, paras $31-32$. 
that an accused person be represented by a lawyer and that the possibility of organise his or her own defence is granted. ${ }^{61}$

Can a defendant refuse to take part in court proceedings held by means of videoconferencing, and instead successfully rely on the European Convention on Human Rights? The Strasbourg Court has held several times that a hearing and a subsequent decision in absentia is also compatible with the right to be heard, if the latter is in fact willingly not exercised by the applicant. At this regard, the burden of proving such a subjective condition may be excessive for an applicant. In this case, a trial in absentia results in a violation of the Convention, insofar as concerns the right to be heard, according to the Sejdovic case law, ${ }^{62}$ only where an unequivocal expression of a will to appear before the court is expressed by the defendant and either no public interest can justify a denial of this or the applicant has sought to escape judicial trial. In Sejdovic no official notice was served on the applicant, and therefore the Court found that he could not be regarded as having been sufficiently aware of his prosecution and the trial to be able to decide to waive his right to appear in court, or to be deemed to have evaded justice.

As result of the above considerations, the right to be present in court cannot be confused with a right of personal attendance. It has been held ${ }^{63}$ that participation at a distance in a hearing by means of videoconferencing is compatible with the right to a defence, but it requires that certain results be met. In particular, the effectiveness of the participation of the accused in the proceedings is a proportionate measure, taking into account the need for the expeditious handling of proceedings involving accused persons in detention.

\section{Videoconferencing and the right to a public hearing}

The Covid-19 outbreak has in practice led to exceptional measures preventing physical access to court buildings and, subsequently, the possibility of public hearings of the classic kind for months. In the Netherlands, the buildings of the district courts were closed from 17 March 2020 until 11 May 2020 to prevent the spread of the coronavirus. Due to this closure, no court hearing could be held in facilities that were usually open to the public. On this issue, we would like to draw attention to two interesting rulings by the administrative jurisdictional division of the Council of State, the findings in which explicitly refer only to the period between 17 March 2020 and 11 May 2020.

The first judgment is about hearings in detention cases of foreign nationals. ${ }^{64}$ In the Netherlands, foreign nationals who appeal against a detention measure are always heard by a court. Hearings often take place physically in court buildings, but facilities

\footnotetext{
${ }^{61}$ That was not the case in ECtHR 1 February 2005, No. 61821/00, Ziliberberg v Moldova, CE:ECHR: 2005:0201JUD006182100, para 41, where the applicant was prevented from organising his own defence since he had no prior notice of the hearing of the appeal.

${ }^{62}$ ECtHR Sejdovic v Italy, supra n. 27, para 98.

${ }^{63}$ See Italian Constitutional Court 22 July 1999, No. 342, IT:COST:1999:342.

${ }^{64}$ Council of State 7 April 2020, 202001949/1/V3, ECLI:NL:RVS:2020:991.
} 
in detention centers are also used regularly to hear foreign nationals at a distance by means of videoconferencing. The 'video conference decision' of 2006 both allows and regulates this method. Under Covid-19 exceptional measures, however, physical hearings could no longer be held at all. Videoconferencing was not possible in each instance, because of the limited capacity and the fact that facilities available at the detention centers were too small to comply with the corona measures adopted. The question was whether such a limitation violated a foreign national's right to be heard.

The Council found that resolving a case in writing was an acceptable temporary solution, if the court had received the consent of both the appellant and the state secretary to do this. What was important was that the fundamental right of the foreign national to be heard not be neglected. Where either the appellant or state secretary would not consent to a written procedure, both parties could agree that only the authorised representatives had to be heard by telephone, as a further temporarily acceptable hearing method. In contrast, where either an authorised representative or a foreign nationalstated that he or she didn't waive the right to be heard physically, the onus was on the court to make every effort to offer the applicant the opportunity to be heard in person. The court might, however, conclude that a hearing was simply not possible in practice due to the Covid-19 outbreak. The Council then deliberated on the consequences of such exceptional circumstances. What was required was to assess the practical impossibility of hearing the foreign national, taking into account other fundamental rights at stake, such as the right to an early decision on the lawfulness of the detention measure, the privacy rights, and the right to health of the applicant and the general importance of public health. The Council concluded that refraining from hearing a foreign national was possible given the special circumstances of the corona crisis, but this could not happen automatically. The court was required to make a recognisable and specific assessment of all the interests involved. The second judgment focused on the temporary emergency ban of public hearings in buildings that were usually publicly accessible. ${ }^{65}$ The judiciary sought a temporary alternative in order to meet the requirement that judgments should be pronounced subject to open scrutiny, and it is relevant for present purposes since it was taken as a reference point by other administrative judgments during the period of time between 17 March 2020 and 11 May 2020.

Pursuant to Article 8:78 of Dutch General Administrative Law Act, a judgment had to be delivered in public, this being a fundamental principle laid down in various human rights treaties (Article 14(1) UN International Covenant on Civil and Political Rights and Article 6(1) of the European Convention on Human Rights). The legislator made reference, inter alia, to the Strasbourg Pretto ruling, ${ }^{66}$ in which it was stated that human rights treaties did not require judgments to be pronounced in public in all cases. Other means of disclosure were permitted as long as anyone could access the full text of the judgment, and Article 8:78 took into account that the internet offered opportunities to give a more contemporary interpretation to the requirement of public disclosure of the judgment.

The Dutch courts usually disclosed a judgment to the parties involved in the dispute by sending a copy of the ruling to them. According to the established case law,

${ }^{65}$ Council of State 7 April 2020, 202002016/1/V3, ECLI:NL:RVS:2020:992.

${ }^{66}$ ECtHR 8 December 1983, No. 7984/77, Pretto v Italy, ECLI:CE:ECHR: 1983: 1208JUD000798477. 
others, who were not involved in the procedure, had to be able to read the judgment in a simple manner. As long as there was no suitable form of digital disclosure, holding 'disclosure sessions', accessible to the public, was an adequate measure to meet the requirements for the disclosure of judgments. The minutes of the hearings, including the case number and the names of the parties, and the relevant decisions, had then be made available for scrutiny by the public in the court's registry.

Under the Covid-19 outbreak the Council found that district courts might suspend the 'disclosure sessions', and took the view that the publication of the full text of judgments on the internet (via www.rechtspraak.nl) provided easy access to them for interested parties. As publication of all judgments was not yet possible due to the limited capacity of the court administration, a possible alternative was to make available and free of charge an official record of the judgments taken on the same day. The interested parties were then allowed to get a copy of the judgment. The Council accepted this method acknowledging that the courts had already tried to publish as many judgments as possible. Therefore, a combination of sending the judgement to the parties and providing an opportunity for others to become aware of the content of the decision by means of the internet or through publication of official records was an acceptable temporary solution and did justice to the essence of the principle of public justice, given the current exceptional circumstances.

\section{Conclusion}

In conclusion, there are significant differences in the respective scopes of Articles 6 and 13 of the European Convention on Human Rights and Article 47 Charter of Fundamental Rights of the European Union. However, both the Convention on Human Rights (an instrument of international law) and EU law (a proper international legalsystem) guarantee the right to effective remedies and the right to a fair trial. Both clearly need to be respected while using videoconferencing for court proceedings.

The Strasbourg case-law on Articles 6 and 13 of the Convention is a key factor in interpreting the meaning of the right to an effective remedy and the right to a fair trial as fundamental EU rights enshrined in Article 47 Charter. The Convention protects both freedoms autonomously as human rights, and Article 6(1) might be considered as constituting a lex specialis in relation to Article 13, depending on the facts underpinning a given case. There are exceptions however, notably in immigration cases, where Article 13 rules out Article 6 ratione materiae, according to the Court's caselaw.

Given its relative nature, the right to be heard is constantly balanced with other fundamental rights. Such freedom is primarily enforced at national level (on the basis of subsidiarity), and extensive use of the relevant Strasbourg case law by domestic courts normally prevents deep review by the Court of Human Rights as well as by the Luxembourg Court. Such use strengthens any court decision. Several Covid-19 emergency measures have been already challenged at national level, and further litigation in front of European international Courts is expected.

In this picture, extensive videoconferencing in court proceedings is encouraged by the Covid-19 emergency regulation in many EU Countries, to contribute to cope with 
the health crisis and prevent a full stop of the jurisdiction. However, it raises new challenges for the exercise of the right to be heard, which requires careful protection, mostly at national level and especially at first instance.

Videoconferencing in court is not at all a new tool. It has been already implemented in many European States in civil and criminal proceedings and enjoys an established legal framework within the Union. ${ }^{67}$ However, in fact, although the EU has encouraged videoconferencing as a key part of its e-Justice plan, ${ }^{68}$ prior to the Covid-19 crisis it was generally used in specific procedures only, such as cross-border legal proceedings, or for peculiar court activities, for instance vulnerable victim hearings to be carried out from separate facilities for protection needs, or witnesses taken in organised crime trials.

The new approach differs from the previous one, since it aims to carry out to the greatest extent possible any hearing activity through videoconferencing so as to reduce effectively health risks which would stem from being physically present in court. Is it merely a quantitative massive adoption of an already well-known item in the toolbox of lawyers and judges? Or can it, through indiscriminate use, have a qualitative impact on the exercise of jurisdiction, especially at first instance, where the core evidence is taken before a judge and the right to be heard is traditionally exercised by a defendant in a classic public hearing? Is the option of using videoconferencing in court something solely for courts themselves, or is it already within the scope of the right of defence and thus something which needs in principle to be accepted by the parties?

This survey shows that it is not easy to give a plain answer to such questions. There are preconditions which must always be checked before any videoconferencing session, and which can not be taken for granted. This is particularly the case if some speakers during a court session (such as experts or witnesses) are not professional legal representatives and are connected from different facilities. It is important that they understand practical arrangements for videoconferencing, and use as hardware technical equipment which provides a stable connection. The software should also be standardised to the greatest extent possible insofar as concerns its class and configuration, so as to facilitate interoperability between equipment and speech intelligibility, and to reduce delays in video and audio data transmission as well as any risks of speak-over. ${ }^{69}$

All participants to the session, especially the judge, should be able to recognise each other visually, and to see both the speaker asking questions or making statements

6729 May 2000 Convention on Mutual Assistance in Criminal Matters between the EU Member States, Art. 10; 28 May 2001 Council Regulation (EC) No 1206/2001 on Cooperation between the national Courts in the Taking of Evidence in Civil and Commercial Matters, Art. 10(4) and 17(4); 29 April 2004 Council Directive 2004/80/EC on Compensation to Crime Victims (2004/80/EC) Art. 9(1); 11 July 2007 Regulation (EC) of the European Parliament and of the Council No 861/2007 establishing a European Small Claims Procedure, Art. 8 and 9(1); 25 October 2012 Directive 2012/29/EU of the European Parliament, replacing Council Framework Decision 2001/220/JHA.

${ }^{68}$ Multi-annual European e-Justice action plan 2009-2013 (2009/C 75/01), OJ C 75, 31.3.2009, 1.

${ }^{69}$ Hearings by phone, where the judge has no visual contact with the parties and the other persons involved, need a further in-depth check of such aspects so as to comply with the outlined fundamental rights enshrined in Article 6 and 13 of the European Convention on Human Rights and Article 47 of the EU Charter. 
when he or she can be heard, and the reaction of the listeners, without missing words during the duration of the videoconferencing. Moreover, privacy requirements need to be met to assure that no extraneous interference or unofficial recording can take place, and also so that after closing the open session the former participants themselves cannot re-enter the virtual court room without authorisation.

As regards the content of the videoconferencing session, in the authors' view, there is no need for an ideological approach to this matter, such as a universal generalisation in favour of or against a new perspective on the conduct of ordinary court proceedings. The proposed approach here, as a result of the survey, suggests distinguishing case-by-case three different scenarios: hearing activities that are well or even better performed by videoconferencing rather than in the conventional way; activities that can be carried out using such a tool but at the cost of certain complications which must be carefully assessed; and activities that are hardly compatible with videoconferencing.

As an example of the first option, videoconferencing could grant exhaustive protection of the right of defence as a means of reducing the discomfort which could be caused by the journey of a detainee in temporary custody to reach his or her appointed judge so as to submit statements, or to confer with a delegated judge, other than the person entitled to decide.

As regards the second scenario, let us think about proceedings with many defendants and parties, especially if these require interpreters. This is a situation which implies connections being established not just point-to-point, between two locations or a few more, but rather multi-point, simultaneously between many locations, and consequently putting at serious risk the meeting of certain preconditions already mentioned concerning the efficiency and real awareness of videoconferencing for each participant.

Thirdly, although the taking of evidence is possibly one of the most important uses of court videoconferencing, a confrontation between witnesses on opposing sides in criminal proceedings is probably not fully compatible with the above-mentioned fundamental rights, by reason of the psychological implications of judicial assessment on the reliability of conflicting witnesses (which is not confined to a mere check of the logical internal coherence of the content of each statement).

Our analysis suggests seeing videoconferencing in court not as a 'value in itself' but as a 'modular protection' instrument both for the judiciary and for lawyers, that could serve hearings, eventually chosen under certain preconditions and that can be used to carry out most but not every judicial activity. Statutory law to regulate the matter consistently and in full harmony with existing legal procedural rules - and therefore not as an emergency remedy just to confront a new resurgence of the virus is highly desirable.

Best practices already established in courts favour the adoption of videoconferencing as much as possible with the parties' agreement rather than by means of a court order. At least in civil and administrative matters, there is a strong interest from most parties to get through hearings quickly and a flexible tool such as videoconferencing is definitely an option. The scope of a videoconferencing session is clearly to let participants be in a position as close as possible to the usual practice in a physical court room. However, systematic and indiscriminate use of this device, especially if 
imposed on parties in taking evidence at first instance, may not be neutral, and may have an impact both on the outcome and on the public perception of the ruling.

A final issue deserving attentive care is the use of commercial products. Mere deliberative activity requires strict confidentiality, and hearing sessions have specific technical requirements as well. Authorities have temporarily found commercial devices acceptable given the importance of keeping the judicial machinery working during the health crisis, but improvements are required. Such instruments, however, designed for general business, are not specifically intended for or tailored to the needs of an ordinary hearing where the different role of the participants (such as defendant, lawyer, judge, public prosecutor, witness, chancellor or expert) implies different credits to be taken into account to properly govern the interactions between them. Specific technological instruments conceived by a legal design task force are recommended in order to comply fully with the right to a fair trial and the right to privacy.

In conclusion, we need to learn from the severe Covid-19 pandemic crisis, since our national legal systems and court functioning may be exposed to other extraordinary conditions in the close future, well after the current resurgence of the virus is over. It is not desirable that democracy be locked down for months: we need to value the terrible experience of the Spring 2020 and to use it to enforce the ordinary rule of law in our democratic societies even in exceptional situations. Mastering videoconferencing in court proceedings, under the conditions outlined here, could effectively contribute to such a goal.

Publisher's Note Springer Nature remains neutral with regard to jurisdictional claims in published maps and institutional affiliations. 